\title{
A NEURAL NETWORK ANALYSIS OF THE FIXED CAPITAL INVESTMENT TRENDS IN REGIONS OF THE RUSSIAN FEDERATION
}
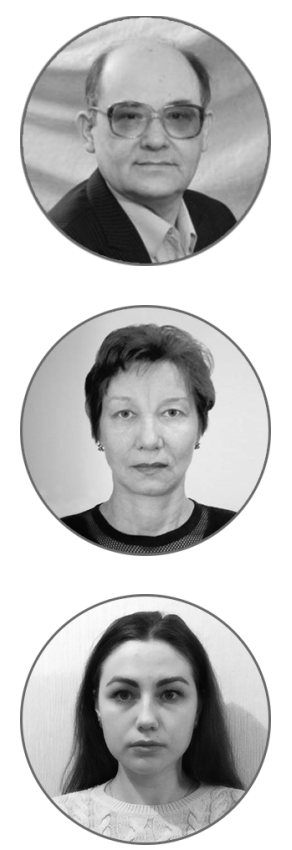

\section{Article history:}

Received 27 January 2017

Received in revised form

10 February 2017

Accepted 27 February 2017

Translated 17 August 2017

Available online 15 September 2017

JEL classification: C15, C45, E22, R11

Keywords: investment behavior, cluster analysis, neural networks, STATISTICA software

\author{
Yurii A. KUZNETSOV \\ National Research Lobachevsky State University of Nizhny Novgorod, \\ Nizhny Novgorod, Russian Federation \\ Kuznetsov_YuA@iee.unn.ru \\ Valentina I.PEROVA \\ National Research Lobachevsky State University of Nizhny Novgorod, \\ Nizhny Novgorod, Russian Federation \\ perova_vi@mail.ru \\ Corresponding author

\section{Elena I. LASTOCHKINA} \\ National Research Lobachevsky State University of Nizhny Novgorod, \\ Nizhny Novgorod, Russian Federation \\ mmep@iee.unn.ru
}

\begin{abstract}
Importance The article considers the changes in and characteristics of the investment activities and behavior of the Russian Federation regions.

Objectives The article aims to analyze and describe the trends and characteristics of fixed capital investment behavior of the Russian Federation regions to ensure the economic growth and socio-economic development of the country and regions.

Methods We examine the regions' investment activities for the period from 2012 through 2014 using the neural modeling methodology on the basis of thirteen indicators characterizing the investment activities of the regions and defining their socio-economic development prospects. We also apply the Self Organizing Map using the STATISTICA software. Data of the Federal State Statistics Service of Russia on fixed investment by type of economic activity in the regions underlie our study.

Results The paper shows certain characteristics and peculiarities of the investment performance and behavior of the Russian Federation regions.

Conclusions and Relevance The cluster analysis of the Russian Federation regions' investment activities shows their uneven nature. The findings indicate the need for comprehensive measures to help change the structure of the investments involved and stimulate investment activity in all regions of the Russian Federation.
\end{abstract}

๑) Publishing house FINANCE and CREDIT, 2017

The editor-in-charge of this article was Irina M. Komarova

Authorized translation by Irina M. Komarova 


\section{Introduction}

The existing economic policy pursues the sustainable development and growth of the Russian economy, as whole, and its regions, in particular. Rapid economic growth can be driven with effective investing activities intended to increase the public welfare and competitive position of the Russian regions ${ }^{1}$.

Currently, the Russian Federation adheres to its resource-export strategy, makes lean investment in researches and has a relatively small market share of knowledge-intensive sectors. The construction of new facilities, equipment repair and refurbishment, purchase of transport, tools and supplies, and other relevant development-oriented activities depend on investment in fixed assets $^{2}$. This idea is expressed in proceedings by O.A. Donichev, O.G. Molchanova and I.V. Tozhokin ${ }^{3}$, P.B. Boldyrevskii and L.A. Kistanova ${ }^{4}$, etc. If more investment is injected in the fixed capital, it will ensure flexible pricing for products, increase the profit, segment and renovate the production process, boost its competitiveness and the agricultural sector ${ }^{5}$ and improve the standard of living in Russia.

Investment in education and respective indicators are important metrics. The body of accumulated knowledge, skills and competence a person acquires in the process of his/her training constitutes a part of human capital (please refer to Yu.A. Kuznetsov ${ }^{6}$ ).

\footnotetext{
${ }^{\dagger}$ For the source article, please refer to: Кузнецов Ю.А., Перова В.И., Ласточкина Е.И. Нейросетевой анализ динамики инвестиций в основной капитал регионов Российской Федерации. Региональная экономика: теория и практика. 2017. Т. 15. Вып. 7. С. 1327-1343. URL: https://doi.org/10.24891/re.15.7.1327

${ }^{1}$ Russian Presidential Decree On Long-Term State Policy of May 7, 2012 № 596.

${ }^{2}$ Federal Law On Investing Activities in the Russian Federation Through Capital Investment of February 25, 1999 № 39-Ф3.

${ }^{3}$ Donichev O.A., Molchanova O.G., Tozhokin I.V. [Evaluation of the effectiveness of investment in the creation of socio-economic clusters in the region]. Regional'naya ekonomika: teoriya i praktika = Regional Economics: Theory and Practice, 2015, no. 5, pp. 2-12. (In Russ.)

${ }^{4}$ Boldyrevskii P.B., Kistanova L.A. [Analyzing the innovation and investment activities of Russian agricultural engineering companies]. Ekonomicheskii analiz: teoriya i praktika = Economic Analysis: Theory and Practice, 2016, no. 2, pp. 159-168. (In Russ.)

${ }^{5}$ Russian Presidential Decree On Measures for the State Science and Technological Policy Enforcement for Agriculture of July 21, 2016 № 350.

${ }^{6}$ Kuznetsov Yu.A. [Human capital, labor productivity and economic growth. Part 1]. Ekonomicheskii analiz: teoriya i praktika = Economic Analysis: Theory and Practice, 2012, no. 43, pp. 2-17. (In Russ.); Kuznetsov Yu.A. [Human capital, labor productivity and economic growth. Part 2].
}

Human capital is one of the most crucial drivers that move the economic capability of the nation forward (I.V. Soboleva, Yu.A. Kuznetsov, O.V. Michasova, Yu.A. Umilina, K. Lajili, C.A. Ibarra [1-6]). Being a combination of economic, political, legislative and social aspects inherent to the region, the investment climate can be affected in the following cases below:

- flight of the national investment capital from Russia to other countries;

- high corruption in the realms of entrepreneurship;

- economic crimes and abuses;

- ineffective law enforcement and significant monopolization.

These issues are tackled at the governmental level. The factors below may better the investment climate and bolster economic activities in regions in a short run:

- lifting of quotas for hiring foreign specialists;

- optimization of the mechanism for managing expenditures for R\&D, experimental and designing work;

- introduction of simplified customs clearance for high technology manufacturers, etc.

Attempting to find an effective set of measures so to attract investment in the Russian regions, decision-makers shall study investing activities and perform a respective scholarly analysis.

Studying economic processes and analyzing investing activities subsequently, it is necessary to draw upon robust Information Technologies, which allow identifying and considering patterns of investing activities in regions. Such technologies include inter alia methods of neural network modeling as presented in proceedings by S. Haykin [7], D.-E. Baestaens, W.-M. Van Den Berg, D. Wood [8], V.V. Kruglov, V.V. Borisov [9], S. Osovskii [10] and G.J. Deboek, T. Kohonen [11]. These methods proved to be an effective tool to analyze big statistical data when both linear and non-linear dependencies are in place. A neural approach is free from model restrictions. There are multiple artificial networks of various types. What makes them different is the way neurons are interconnected and the way

Ekonomicheskii analiz: teoriya i praktika = Economic Analysis: Theory and Practice, 2012, no. 44, pp. 2-14. (In Russ.)

Please cite this article as: Kuznetsov Yu.A., Perova V.I., Lastochkina E.I. A Neural Network Analysis of the Fixed Capital Investment Trends in Regions of the Russian Federation. Digest Finance, 2017, vol. 22, iss. 3, pp. 258-273. 
their interact. Papers referred hereinafter [12-20] demonstrate how neural network techniques can be successfully applied to financial and economic researches.

Currently, special-purpose software solutions are used to effectuate neural network concepts (V.S. Rastunkov et al. [13], V.S. Medvedev and V.G. Potemkin [14]). In this research, we resort to self-organizing feature maps presented by G.J. Deboeck and T. Kohonen (SOM) [11, 15-17] and thoroughly described in training and methodological literature ${ }^{7}$. Self-organizing feature maps have a crucial distinction from other types of neural networks (S. Rende, M. Donduran [18], O.A. Carboni, P. Russu [19]). They are designed for unsupervised learning, i.e. they shall not be informed of correct answers in the process of learning. Such neural networks are trained using various algorithms. For instance, an algorithm based on competitive unsupervised learning (T. Kohonen [15]), algorithm based on Neural Gas Network (M. Martinetz, S. Berkovich, K. Schulten [20], etc.). SOM algorithms ensure a high-dimensional input data space (this space equals 13 in this article) is displayed as elements of the output layer with the topology being preserved. The output layer of neurons is usually two-dimensional and called the topological map layer. When the topology is preserved in visualization, SOM arrange input data vectors among neurons so that neighboring multivariate space points are visualized as closely located neurons of the topological map. Therefore, such maps are effective tools for clustering and visualizing high-dimensional data (G.J. Deboek and T. Kohonen [11]).

\section{Terminology}

The article deals with the following concepts based on the Official Statistical Methodology for Evaluating the Investment in Fixed Capital at the Regional Level ${ }^{8}$.

\footnotetext{
${ }^{7}$ Balabanov A.S., Strongina N.P. Analiz dannykh v ekonomicheskikh prilozheniyakh [Data analysis in economic software packages]. Nizhny Novgorod, NNSU Publ., 2004, 135 p.; Perova V.I. Neironnye seti v ekonomicheskikh prilozheniyakh. Chast' 2. Neironnye seti, obuchaemye bez uchitelya [Neural networks in economic software packages. Part 2 Unsupervised learning neural networks]. Nizhny Novgorod, NNSU Publ., 2012, 135 p.; Perova V.I. Neironnye seti. Chast' 2 [Neural networks. Part 2]. Nizhny Novgorod, NNSU Publ., 2012, 111 p.

${ }^{8}$ The Official Statistical Methodology for Evaluation of Investment in Fixed Capital at the Regional Level, as approved by Order of the Russian State Statistics Service of September 18, 2014 № 569.
}

Investment shall mean securities, monetary funds and other property, which are contributed to business or other activities for profit-making purposes.

Investing activities stand for investment and profit-making practices or securing any other useful effect.

Fixed assets refer to non-financial constructed assets (a part of the property), which the entity uses on an ongoing or recurring basis for over 12 months in its production and management.

Capital expenditures are investment in fixed capital (fixed assets), which include expenditures for:

- construction of buildings and facilities;

- technological retrofiring and refurbishment of operational entities;

- purchase of equipment, productive and business tools;

- R\&D.

Investment in fixed capital is earmarked by type of economic activities in accordance with the Russian Classifier of Types of Economic Activities (Business Classifier - OKVED). The allocation of investment depends on the purpose of fixed assets, i.e. the area where they will be used.

\section{Neural Network Modeling of Trends in Investing Activities of the Russian Regions: An Analysis of the Outcome}

We examine how investment in fixed capital changed by type of economic activities in the Russian regions, spanning from 2012 through 2014. We rely upon figures released on the website of the Federal State Statistics Service, in the 2014 values, including the inflation"

- $X 1$ refers to the production of mineral resources, million RUB;

- $X 2$ refers to agriculture, hunting and forestry, million RUB;

- $X 3$ refers to processing enterprises, million RUB;

\footnotetext{
${ }^{9}$ Inflation rate in the Russian Federation.

URL: http://уровень-инфляции.рф
} 
- $X 4$ refers to the production and distribution of energy, gas and water, million RUB;

- $X 5$ refers to the construction, million RUB;

- $X 6$ refers to retail and wholesale trade, million RUB;

- $X 7$ refers to hotels and restaurants, million RUB;

- $X 8$ refers to transport and communications, million RUB;

- $X 9$ refers to financial activities, million RUB;

- $X 10$ refers to real estate transactions, lease and services, million RUB;

- $X 11$ refers to public administration, military security, million RUB;

- $X 12$ refers to education, million RUB;

- $X 13$ refers to health care and social security services, million RUB.

Our studies are based on the neural network modeling methodology - the Self-Organizing Maps of Kohonen and implemented in the STATISTICA Neural Networks software, which enables us to cluster the data.

82 regions of the Russian Federation were attributed to the following clusters:

- Cluster 1 includes regions where the above indicators are high;

- Cluster 2 includes regions where the indicators are mainly higher than Russia's average figures;

- Cluster 3 includes regions where the indicators approximate Russia's average figures;

- Cluster 4 includes regions where the indicators are lower than in Cluster 3 and higher than Cluster 5.

Table 1 reflects how many regions are grouped within the clusters, and relevant trends. Having analyzed the data in Table 1, we see that Clusters 4 and 5 embrace many regions, while Clusters 1 and 2 include few ones. The number of regions has changed insignificantly for the period in those clusters where the indicators are average or above average (Clusters 1-3), except for 2014. Clusters 2 and 3 saw considerable rearrangements since Clusters 4 and 5, i.e. clusters with the low investing activities, shrank. Table 2 gives a detailed view of the Russian regions and the cluster they pertain to. Analyzing the data in Table 2, we detect that each cluster has the constant and stable nucleus:

- Cluster 1 nucleus contains Moscow and Saint Petersburg, Moscow Oblast and Krasnodar Krai;

- Cluster 2 nucleus contains the Republic of Tatarstan;

- Cluster 3 nucleus contains the Chechen Republic and Khabarovsk Krai.

Clusters 4 and 5 have the most affluent constant nuclei.

Cluster 4 nucleus combine 16 regions:

- six regions of the Volga Federal District, i.e. Kirov Oblast, Orenburg Oblast, Saratov Oblast, Ulyanovsk Oblast, Republic of Mordovia, Udmurt Republic;

- six regions of the Central Federal District, i.e. Vladimir Oblast, Kaluga Oblast, Orel Oblast, Ryazan Oblast, Tula Oblast, Yaroslavl Oblast;

- two regions of the Northwestern Federal District, i.e. Vologda Oblast and Kaliningrad Oblast;

- a region of the Southern Federal District, i.e. Volgograd Oblast;

- a region of the Siberian Federal District, i.e. Omsk Oblast.

Cluster 5 nucleus accumulated 15 regions:

- five regions of the Central Federal District, i.e. Belgorod Oblast, Ivanovo Oblast, Kostroma Oblast, Kursk Oblast, Tambov Oblast;

- two regions of the Northwestern Federal District, i.e. Republic of Karelia and Pskov Oblast;

- two regions of the Southern Federal District, i.e. Republic of Adygea and Republic of Kalmykia;

- two regions of the North Caucasian Federal District, i.e. Republic of Ingushetia and Karachay-Cherkess Republic;

- a region of the Ural Federal District, i.e. Kurgan Oblast;

- two regions of the Siberian Federal District, i.e. Tyva Republic and Republic of Khakassia; 
- a region of the Far Eastern Federal District, i.e. Jewish Autonomous Oblast.

Seven regions (Amur Oblast, Novgorod Oblast, Sakhalin Oblast, Smolensk Oblast, Tyumen Oblast, Sakha Republic (Yakutia) and Krasnoyarsk Krai) receded from their position in 2014 and entered the clusters with lower indicators of investing activities than before.

The Arkhangelsk Oblast, Leningrad Oblast, Magadan Oblast, Murmansk Oblast, Rostov Oblast, Tver Oblast, Tomsk Oblast, Chelyabinsk Oblast, Kabardino-Balkar Oblast, Republic of North Ossetia - Alania, Republic of Bashkortostan, Altai Republic, Altai Krai, Kamchatka Krai and Chukotka Autonomous Okrug rose in 2014 and entered the clusters with higher indicators of investing activities than before.

Tables 3 and 4 show the average indicators of investing activities and the national average for 2012-2014. As the analysis of the data herein shows, the national average grew in 2014 with respect to some indicators, as compared with 2012:

- production of mineral resources;

- processing enterprises;

- retail and wholesale trade;

- hotels and restaurants;

- finance;

- real estate, lease and services.

The graphs (Fig. 1-4) provide an illustrative view of trends in some averages of fixed capital investment by type of the economic activities in regions for 2012-2014 and respective national averages. As inferred from the analysis of the data in Fig. 1, the average of X1 - Production of Mineral Resources - in Clusters 1 and 2 is five-fold higher than the respective national average, say, in Cluster 1 throughout the entire analyzable period. By contrast, the averages of this indicator in Clusters 4 and 5 are lower than the national average throughout the entire analyzable period.

In Cluster 3, the average of this indicator almost matches the respective national average.

In 2014, if compared with 2013, Cluster 1 relinquished its natural-resource-production indicator (Fig. 1), but more than doubled the processing-enterprises indicator (Fig. 2).

We shall note that the average of $X 3$ - Processing Enterprises - in Clusters 1 and 2 is ranging within the period in question (Fig. 2). Furthermore, the national average of this indicator also assumed an upward trend.

As per Fig. 3, the national average of $X 12$ - Education almost remained flat throughout the entire analyzable period, with investment in education being significantly scarcer than that in the Production of Natural Resources (Fig. 1) and Processing Enterprises (Fig. 2).

The regions in Clusters 1 and 2 take the lead with their $X 12$ - Education. The average of this indicator in the clusters exceeds the national average. By contrast, the education indicator in Clusters 3 and 4 remained lower than the respective national average within the entire period.

Fig. 4 reflects how investment in health care and social security services (X13) changes in clusters within 2012-2014, showcasing the downward trend in this indicator.

The regions in Clusters 1 and 2 make the largest amounts of investment in healthcare and social security services. In 2012 the average of $X 13$ in Cluster 3 was higher, but lagged behind the national average starting from 2013. Furthermore, likewise the investment in education, this indicator is manifold lower than investment in the production of natural resources and processing enterprises.

\section{Conclusion}

We applied neural network modeling methods to analyze how investing activities develop in the regions of the Russian Federation. We trace the uneven pace of the investing activities and detect the significant difference among the size of the clusters and the way they changed. Over 50 regions out of the total number have been attributed to the clusters with low indicators of investing activities. Clusters 4 and 5 happened to include most of the regions within 2012-2014. Cluster 1, which included the regions with the highest indicators of investing activities, almost stalled in its development. The nucleus of the cluster, which contains the highest indicators of fixed capital investment, is comprised of Moscow and Saint Petersburg, Moscow Oblast and 
Krasnodar Krai. The leading group is four-fold smaller than the lagging one in terms of numbers.

As for the mix of fixed capital investment by time of the economic activities, the investment in the production of mineral resources account for the largest share. In this respect, it is important to modify the structure of investment in high technologies ${ }^{10}$.

This initiative requires a set of measures to be undertaken:

- financial aid of the State and private investors to regional investment projects for refurbishment and development of the existing fixed assets and incorporation of new high-tech enterprises;

- increase in the investment attractiveness of places;

- focus on the best-in-class investment practices of the leading regions;
- overcoming of administrative barriers in regions.

Summarizing the findings, we should emphasize it is especially important and interesting to observe the activities regional authorities carry out to improve the investment climate in the constituent entities of the Russian Federation. These efforts are evaluated by the National Rating of Investment Climate in the Russian Regions ${ }^{11}$. As seen therein, many regions in Clusters 4 and 5 are very active in creating a favorable business environment and streamlining the performance of regional management task forces, thus instigating the positions the regions take in the National Rating of Investment Climate.

Our findings may reinforce the quality and reasonableness of managerial decision-making and highlight the regions that need special approaches and support of the State.

\footnotetext{
${ }^{10}$ The Concept for Long-Term Economic Development of the Russian Federation up to 2020, as approved by Resolution of the RF Government of November 17, 2008 № 1662-p.
}

\footnotetext{
${ }^{11}$ National Rating of Investment Climate in the Russian Regions. URL: https://asi.ru/investclimate/rating/
} 
Table 1

Change in the number of regions in clusters

\begin{tabular}{llllll}
\hline \multirow{2}{*}{ Year } & Cluster & \multicolumn{3}{l}{} \\
\cline { 2 - 6 } & $\mathbf{1}$ & $\mathbf{2}$ & $\mathbf{3}$ & $\mathbf{4}$ & $\mathbf{5}$ \\
\hline 2012 & 6 & 7 & 12 & 33 & 24 \\
\hline 2013 & 7 & 5 & 10 & 29 & 31 \\
\hline 2014 & 6 & 11 & 14 & 25 & 26 \\
\hline
\end{tabular}

Source:Authoring

\section{Table 2}

Change in the distribution of regions of the Russian Federation by cluster for 2012-2014

\begin{tabular}{|c|c|c|c|}
\hline \multirow{2}{*}{ Region } & \multicolumn{3}{|c|}{ Cluster Number } \\
\hline & 2012 & 2013 & 2014 \\
\hline Belgorod Oblast & 5 & 5 & 5 \\
\hline Bryansk Oblast & 4 & 5 & 5 \\
\hline Vladimir Oblast & 4 & 4 & 4 \\
\hline Voronezh Oblast & 5 & 5 & 4 \\
\hline Ivanovo Oblast & 5 & 5 & 5 \\
\hline Kaluga Oblast & 4 & 4 & 4 \\
\hline Kostroma Oblast & 5 & 5 & 5 \\
\hline Kursk Oblast & 5 & 5 & 5 \\
\hline Lipetsk Oblast & 4 & 5 & 5 \\
\hline Moscow Oblast & 1 & 1 & 1 \\
\hline Orel Oblast & 4 & 4 & 4 \\
\hline Ryazan Oblast & 4 & 4 & 4 \\
\hline Smolensk Oblast & 4 & 4 & 5 \\
\hline Tambov oblast & 5 & 5 & 5 \\
\hline Tver Oblast & 4 & 4 & 3 \\
\hline Tula Oblast & 4 & 4 & 4 \\
\hline Yaroslavl Oblast & 4 & 4 & 4 \\
\hline Moscow & 1 & 1 & 1 \\
\hline Republic of Karelia & 5 & 5 & 5 \\
\hline Komi Republic & 2 & 3 & 3 \\
\hline Arkhangelsk Oblast & 3 & 3 & 2 \\
\hline Vologda Oblast & 4 & 4 & 4 \\
\hline Kaliningrad Oblast & 4 & 4 & 4 \\
\hline Leningrad Oblast & 4 & 4 & 2 \\
\hline Murmansk Oblast & 5 & 3 & 2 \\
\hline Novgorod Oblast & 4 & 4 & 5 \\
\hline Pskov Oblast & 5 & 5 & 5 \\
\hline Saint Petersburg & 1 & 1 & 1 \\
\hline Republic of Adygea & 5 & 5 & 5 \\
\hline Republic of Kalmikia & 5 & 5 & 5 \\
\hline Krasnodar Krai & 1 & 1 & 1 \\
\hline Astrakhan Oblast & 3 & 5 & 3 \\
\hline Volgograd Oblast & 4 & 4 & 4 \\
\hline Rostov Oblast & 4 & 4 & 2 \\
\hline Republic of Dagestan & 3 & 4 & 3 \\
\hline Republic of Ingushetia & 5 & 5 & 5 \\
\hline Kabardino-Balkar Republic & 5 & 5 & 4 \\
\hline
\end{tabular}

Please cite this article as: Kuznetsov Yu.A., Perova V.I., Lastochkina E.I. A Neural Network Analysis of the Fixed Capital Investment Trends in 264 Regions of the Russian Federation. Digest Finance, 2017, vol. 22, iss. 3, pp. 258-273. https://doi.org/10.24891/df.22.3.258 


\begin{tabular}{|c|c|c|c|}
\hline Karachay-Cherkess Republic & 5 & 5 & 5 \\
\hline Republic of North Ossetia - Alania & 5 & 5 & 3 \\
\hline Chechen Republic & 3 & 3 & 3 \\
\hline Stavropol Krai & 3 & 5 & 4 \\
\hline Republic of Bashkortostan & 3 & 4 & 2 \\
\hline Mari El Republic & 4 & 5 & 5 \\
\hline Republic of Mordovia & 4 & 4 & 4 \\
\hline Republic of Tatarstan & 2 & 2 & 2 \\
\hline Udmurt Republic & 4 & 4 & 4 \\
\hline Chuvash Republic & 4 & 5 & 4 \\
\hline Perm Krai & 4 & 3 & 4 \\
\hline Kirov Oblast & 4 & 4 & 4 \\
\hline Nizhny Novgorod Oblast & 3 & 2 & 3 \\
\hline Orenburg Oblast & 4 & 4 & 4 \\
\hline Penza Oblast & 4 & 5 & 5 \\
\hline Samara Oblast & 3 & 2 & 4 \\
\hline Saratov Oblast & 4 & 4 & 4 \\
\hline Ulyanovsk Oblast & 4 & 4 & 4 \\
\hline Kurgan Oblast & 5 & 5 & 5 \\
\hline Sverdlovsk Oblast & 4 & 2 & 2 \\
\hline Khanty-Mansi Autonomous Okrug & 2 & 1 & 1 \\
\hline Yamal-Nenets Autonomous Okrug & 2 & 1 & 4 \\
\hline Tyumen Oblast & 1 & 1 & 5 \\
\hline Altai Republic & 5 & 5 & 3 \\
\hline Republic of Buryatia & 5 & 3 & 5 \\
\hline Tyva Republic & 5 & 5 & 5 \\
\hline Republic of Khakassia & 5 & 5 & 5 \\
\hline Altai Krai & 4 & 5 & 3 \\
\hline Zabaykalsky Krai & 2 & 3 & 2 \\
\hline Krasnoyarsk Krai & 2 & 2 & 3 \\
\hline Irkutsk Oblast & 4 & 3 & 3 \\
\hline Kemerovo Oblast & 4 & 4 & 3 \\
\hline Novosibirsk Oblast & 3 & 5 & 4 \\
\hline Omsk Oblast & 4 & 4 & 4 \\
\hline Tomsk Oblast & 4 & 4 & 3 \\
\hline Sakha Republic (Yakutia) & 2 & 4 & 5 \\
\hline Kamchatka Krai & 5 & 5 & 2 \\
\hline Primorsky Krai & 1 & 4 & 2 \\
\hline Khabarovsk Krai & 3 & 3 & 3 \\
\hline Amur Oblast & 3 & 4 & 5 \\
\hline Magadan Oblast & 5 & 5 & 3 \\
\hline Sakhalin Oblast & 3 & 3 & 5 \\
\hline Jewish Autonomous Oblast & 5 & 5 & 5 \\
\hline Chukotka Autonomous Okrug & 5 & 5 & 2 \\
\hline Chelyabinsk Oblast & 4 & 4 & 2 \\
\hline
\end{tabular}

Source: Authoring 
Table 3

Statistics of the average values of investment activity $X 1-X 7$ indicators in clusters and all regions of the Russian Federation

\begin{tabular}{|c|c|c|c|c|c|c|c|c|}
\hline Year & $\begin{array}{l}\text { Cluster } \\
\text { Number, } M_{Y^{*}} \text {. }\end{array}$ & $X 1$ & $X 2$ & $X 3$ & $X 4$ & $x 5$ & $x 6$ & $x 7$ \\
\hline \multirow[t]{6}{*}{2012} & 1 & $172,773.11$ & $7,205.76$ & $57,995.07$ & $72,392.94$ & $14,698.98$ & $27,302.66$ & $3,907.8$ \\
\hline & 2 & $183,003.36$ & $3,872.19$ & $31,537.03$ & $31,497.24$ & $10,254.96$ & $2,395.4$ & 557 \\
\hline & 3 & $24,248.89$ & $4,651.7$ & $22,888.3$ & $13,175.76$ & $2,999.2$ & $2,324.84$ & 275.07 \\
\hline & 4 & $10,884.18$ & $3,249.1$ & $24,644.97$ & $13,392.25$ & $1,205.37$ & $2,357.16$ & 170.35 \\
\hline & 5 & $4,709.2$ & $3,554.8$ & $4,337.13$ & $7,134.73$ & 653.93 & 857.81 & 78.39 \\
\hline & $M_{2012}$ & $37,571.31$ & $4,245.74$ & $21,472.73$ & $17,391.77$ & $3,066.34$ & $3,742.14$ & 465.23 \\
\hline \multirow[t]{6}{*}{2013} & 1 & $28,3671.83$ & $7,397.93$ & $57,746.4$ & $54,956.78$ & $21,393.71$ & $23,113.44$ & $9,657.89$ \\
\hline & 2 & $42,756.86$ & $5,209.61$ & $98,546.05$ & $36,121.93$ & $3,077.7$ & $5,853.79$ & $1,006.69$ \\
\hline & 3 & $35,535.2$ & 5,101 & $21,662.06$ & $7,221.93$ & $2,877.83$ & $1,029.76$ & 118.02 \\
\hline & 4 & $11,191.88$ & $1,362.28$ & $17,642.73$ & $13,346.43$ & $1,678.51$ & $2,777.96$ & 192.98 \\
\hline & 5 & $3,865.58$ & $4,022.77$ & $6,271.37$ & $6,353.32$ & 885.29 & $1,275.34$ & 161.48 \\
\hline & $M_{2013}$ & $37,016.4$ & $4,413.06$ & $23,121.89$ & $14,896.66$ & $3,293.22$ & $3,920.21$ & $1,029.52$ \\
\hline \multirow[t]{6}{*}{2014} & 1 & $264,681.42$ & $6,781.42$ & $146,622.26$ & $51,175.38$ & $17,227.08$ & $27,702.66$ & $11,535.99$ \\
\hline & 2 & $69,540.35$ & $4,513.19$ & $44,993.24$ & $24,695.7$ & $5,639.89$ & $3,489.19$ & 871.19 \\
\hline & 3 & $31,450.12$ & $4,366.21$ & $29,739.53$ & $11,281.84$ & $2,536.91$ & $1,915.06$ & 254.12 \\
\hline & 4 & $8,839.18$ & $4,298.83$ & $6,094.79$ & $12,224.7$ & $1,106.88$ & $2,433.07$ & 153.28 \\
\hline & 5 & $2,656.7$ & $1,361.51$ & $4,723.84$ & $4,253.37$ & 356.92 & 923.53 & 121.17 \\
\hline & $M_{2014}$ & $37,602.29$ & $4,029.11$ & $28,369.44$ & $14,059.22$ & $2,900.85$ & $3,856.66$ & $1,089.5$ \\
\hline
\end{tabular}

Note. $M_{\gamma^{*}}$ stands for the averages of all the regions in the $Y$-year.

Source: Authoring 
Table 4

Statistics of the average values of investment activity $X 8-X 13$ indicators in clusters and all regions of the Russian Federation

\begin{tabular}{|c|c|c|c|c|c|c|c|}
\hline Year & $\begin{array}{l}\text { Cluster } \\
\text { Number, } M_{Y^{*}} \text {. }\end{array}$ & $x 8$ & $X 9$ & $X 10$ & $X 11$ & $X 12$ & $X 13$ \\
\hline \multirow[t]{6}{*}{2012} & 1 & $178,874.29$ & $22,338.28$ & $84,569.23$ & $13,600.67$ & $13,669.2$ & $12,779.89$ \\
\hline & 2 & $77,356.23$ & $2,348.17$ & $21,547.7$ & $3,290.98$ & $6,139.61$ & $5,464.06$ \\
\hline & 3 & $35,231.58$ & $2,480.81$ & $10,267.55$ & $5,227.65$ & $3,070.36$ & $4,290.69$ \\
\hline & 4 & $24,843.65$ & $1,398.79$ & $8,164.48$ & $1,682.62$ & $2,197.05$ & $3,083.65$ \\
\hline & 5 & $7,026.66$ & 503.83 & $2,667.84$ & $1,424.72$ & $1,051.76$ & $1,387.4$ \\
\hline & $M_{2012}$ & $36,902.42$ & $2,908.4$ & $13,596.53$ & $3,135.28$ & $3,165.62$ & $3,676.52$ \\
\hline \multirow[t]{6}{*}{2013} & 1 & $191,260.31$ & $14,097.54$ & $70,067.6$ & $11,013.98$ & $10,408.7$ & $9,014.4$ \\
\hline & 2 & $42,771.24$ & $3,833.86$ & 30,523 & $4,846.5$ & $6,528.24$ & $6,194.47$ \\
\hline & 3 & $29,522.46$ & $2,077.23$ & $8,746.4$ & $6,118.2$ & $2,417.57$ & $2,541.8$ \\
\hline & 4 & $20,392.27$ & $1,107.03$ & $8,803.29$ & $1,661.08$ & $2,528.05$ & $2,476.65$ \\
\hline & 5 & $9,175.02$ & 866.37 & $4,476.16$ & $1,285.58$ & $1,466.38$ & $1,343.11$ \\
\hline & $M_{2013}$ & $33,215.9$ & $2,409.59$ & $13,714.73$ & $3,055.33$ & $3,029.86$ & $2,840.86$ \\
\hline \multirow[t]{6}{*}{2014} & 1 & $168,838.8$ & $42,370.19$ & $96,959.72$ & $10,026.63$ & $11,870.57$ & $9,320.83$ \\
\hline & 2 & $34,737.16$ & $1,760.61$ & $20,651.51$ & $7,058.42$ & $4,995.39$ & $4,072.57$ \\
\hline & 3 & $25,453.39$ & $1,036.04$ & $8,762.26$ & $2,506.21$ & $2,761.02$ & $1,807.03$ \\
\hline & 4 & $13,535.51$ & 867.09 & $9,248.76$ & $1,707.22$ & 2,288 & $1,469.76$ \\
\hline & 5 & $6,098.98$ & 390.35 & $3,360.92$ & 900.86 & 925.67 & 990.12 \\
\hline & $M_{2014}$ & $27,420.13$ & $3,901.45$ & $15,246.33$ & $2,914.54$ & $3,001.15$ & $2,298.89$ \\
\hline
\end{tabular}

Note. $M_{Y}$. stands for the averages of all the regions in the $\gamma$-year.

Source:Authoring 


\section{Figure 1}

Change in the fixed capital investment by economic activity Mining in 2012-2014, million RUB

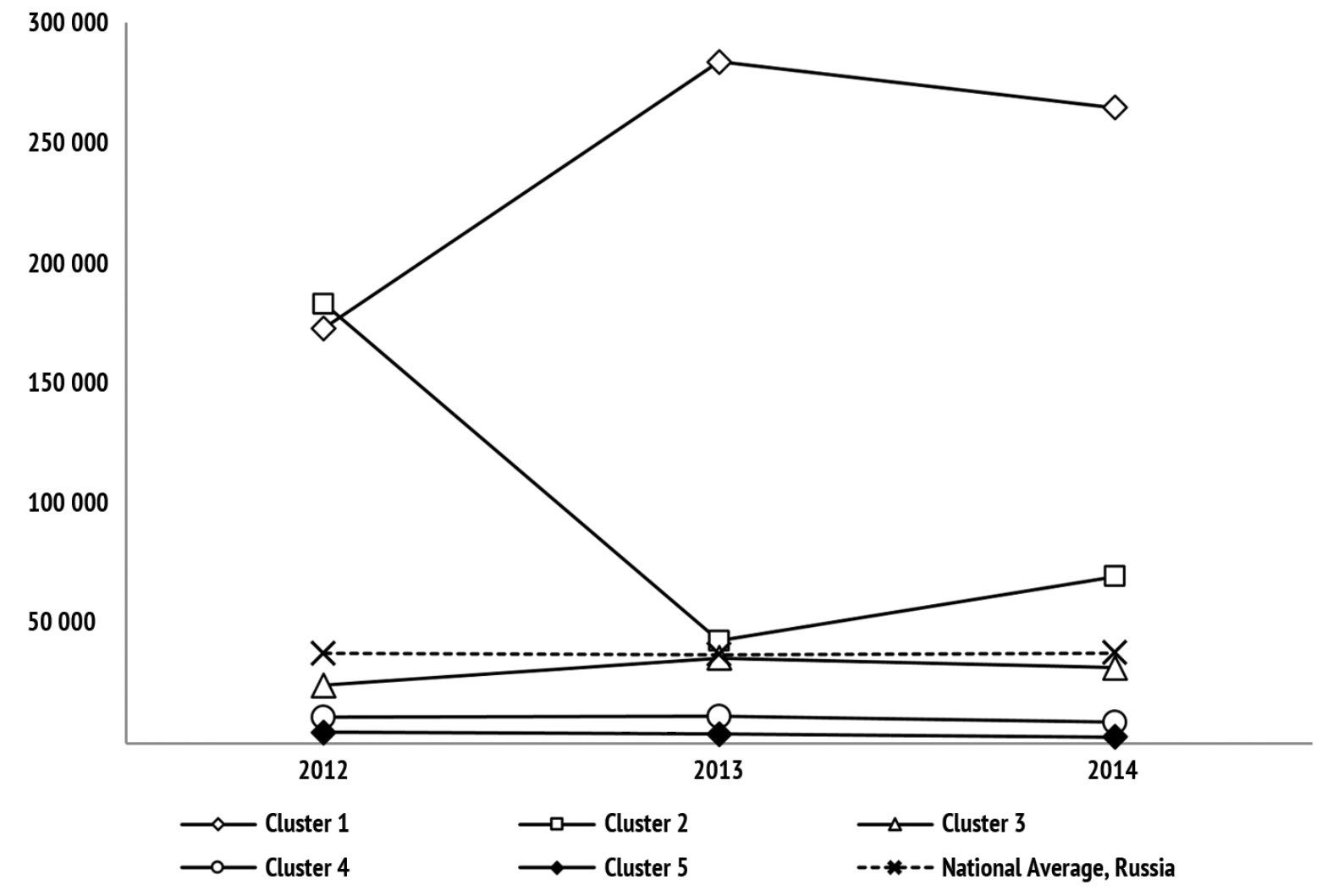

Source: Authoring Regions of the Russian Federation. Digest Finance, 2017, vol. 22, iss. 3, pp. 258-273. https://doi.org/10.24891/df.22.3.258 
Figure 2

Change in the fixed capital investment by economic activity Manufacturing in 2012-2014, million RUB

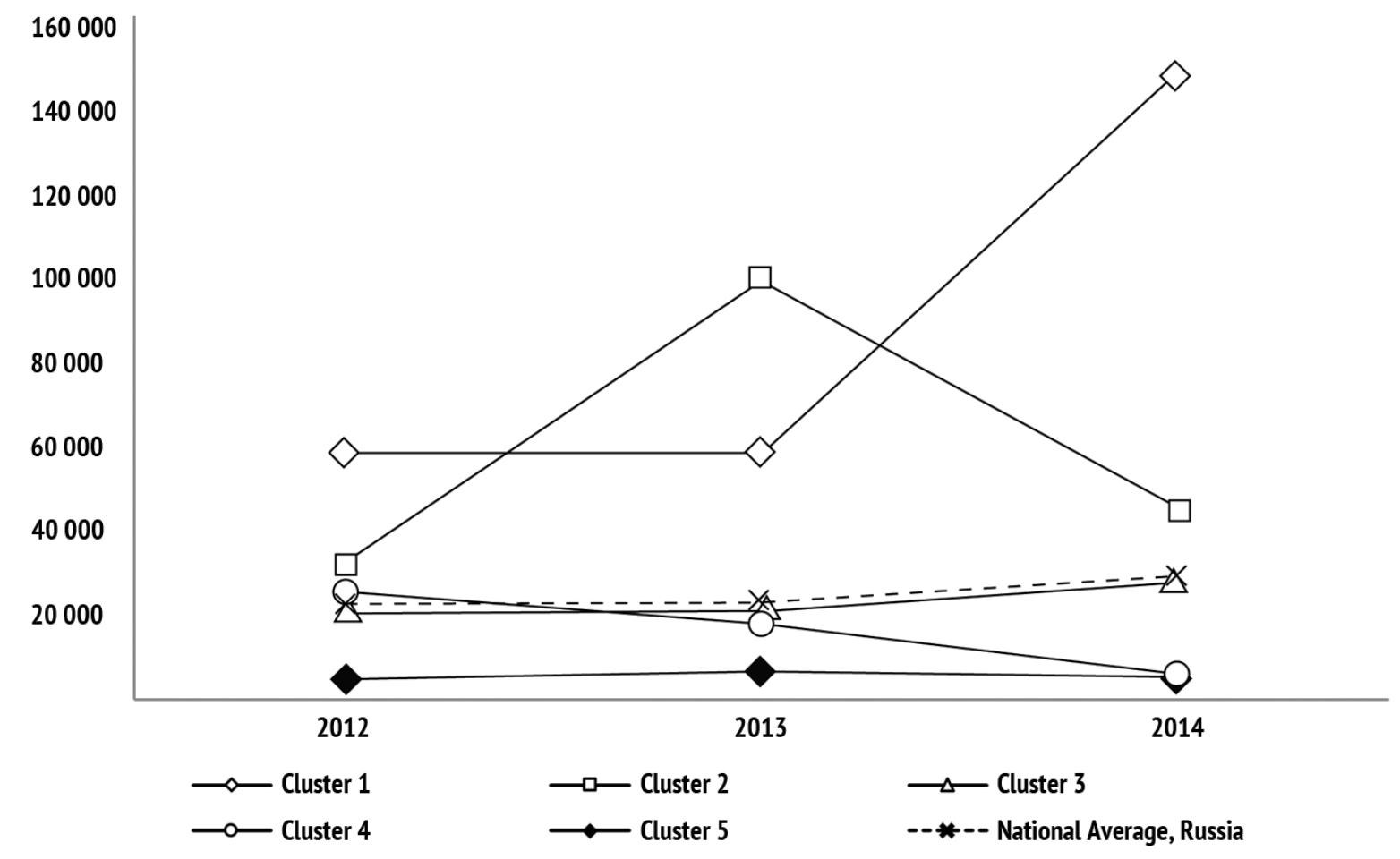

Source: Authoring 


\section{Figure 3}

Change in the fixed capital investment by economic activity Education in 2012-2014, million RUB

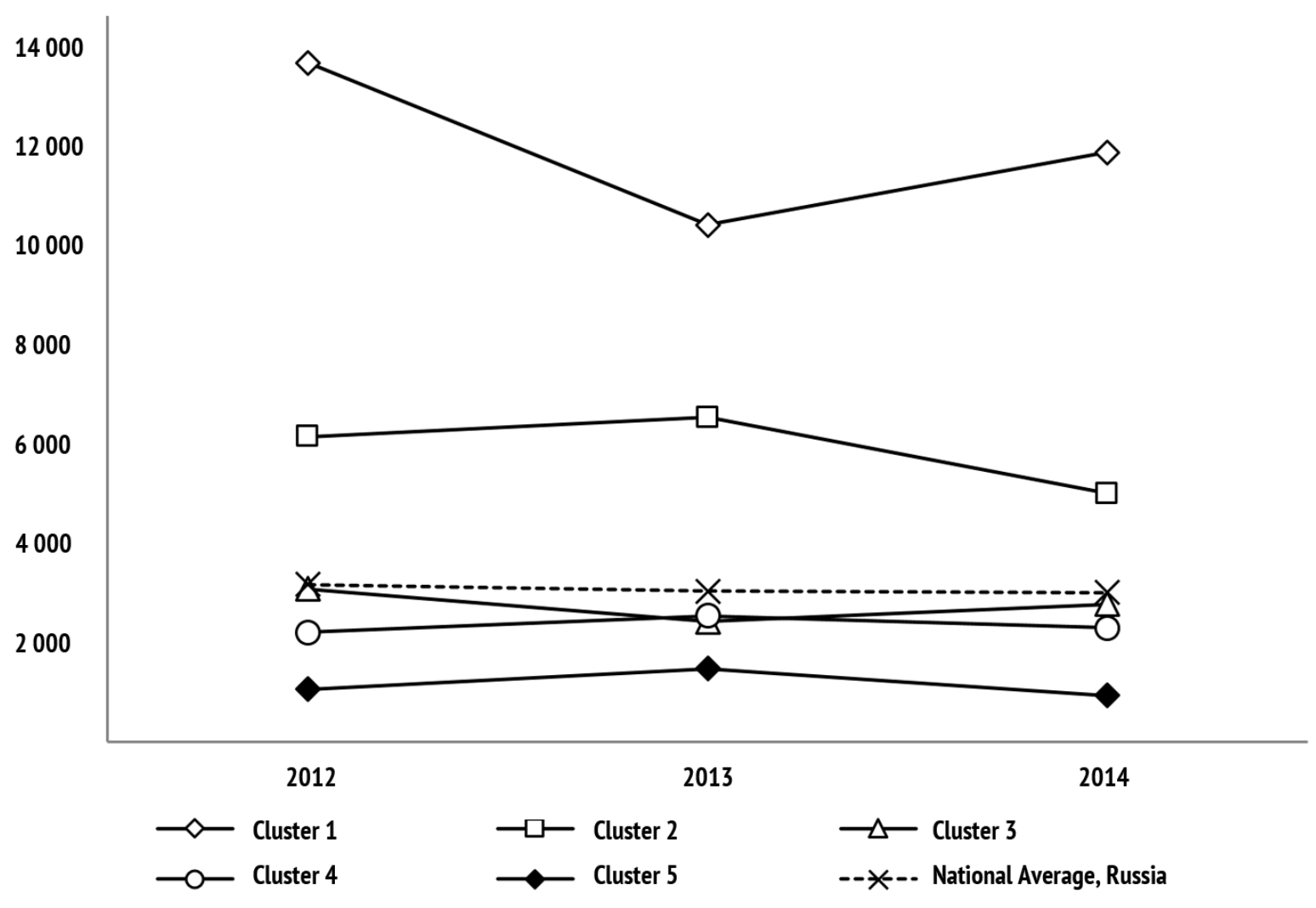

Source: Authoring 


\section{Figure 4}

Change in the fixed capital investment by economic activity Health and Social Services in 2012-2014, million RUB

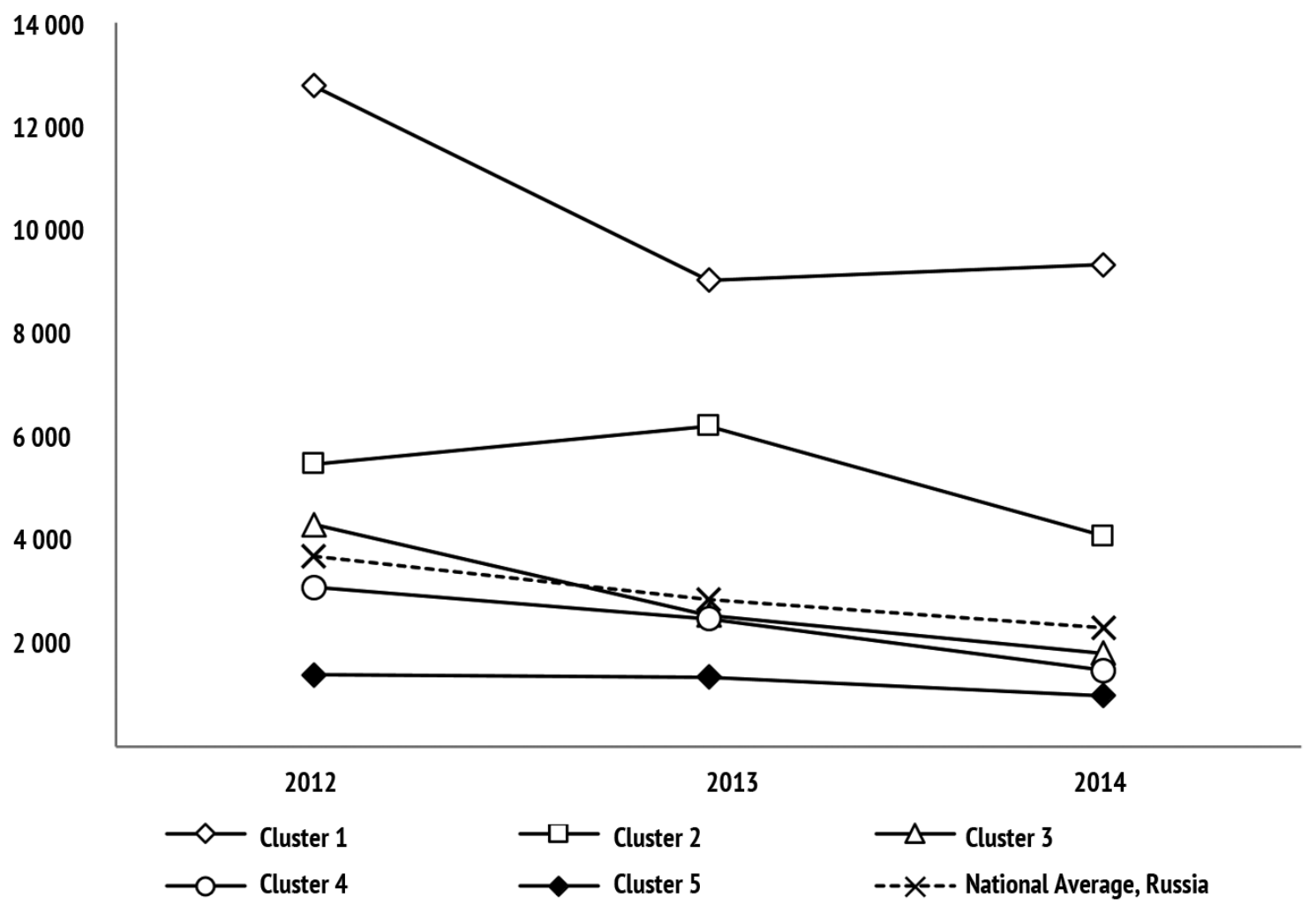

Source:Authoring

\section{Acknowledgments}

The article was supported by the Publishing house FINANCE and CREDIT's Information center at the National Research Lobachevsky State University of Nizhny Novgorod.

We express our profound gratitude and appreciation to Nikolai P. LYUBUSHIN, Doctor of Economic Sciences, Professor, for valuable consideration of the results presented in the article and a number of helpful comments on the manuscript. 


\section{References}

1. Soboleva I.V. [Paradoxes of human capital measurement]. Voprosy Ekonomiki, 2009, no. 9, pp. 51-70. (In Russ.)

2. Soboleva I. Paradoxes of the Measurement of Human Capital. Problems of Economic Transition, 2010, vol. 52, no. 11, pp. 43-70.

3. Kuznetsov Yu.A., Michasova O.V. [Formalization of the task of identifying and analyzing the main economic growth determinants in Russia]. Vestnik Nizhegorodskogo universiteta im. N.I. Lobachevskogo. Ser. Sotsial'nye nauki = Vestnik of Lobachevsky State University of Nizhny Novgorod. Ser. Social Sciences, 2015, no. 3, pp. 9-19. (In Russ.) URL: http://www.vestnik.unn.ru/ru/nomera?anum=9375

4. Kuznetsov Yu.A., Umilina A.Yu. [Some features of economic growth in developing countries and a mathematical model of economic growth of the Nelson-Phelps type]. Vestnik Nizhegorodskogo universiteta im. N.I. Lobachevskogo. Ser. Sotsial'nye nauki = Vestnik of Lobachevsky State University of Nizhny Novgorod. Ser. Social Sciences, 2015, no. 4, pp. 36-44. (In Russ.) URL: http://www.vestnik-soc.unn.ru/en/nomera?anum=9471

5. Lajili K. Embedding Human Capital into Governance Design: A Conceptual Framework. Journal of Management \& Governance, 2015, vol. 19, iss. 4, pp. 741-762. URL: https://doi.org/10.1007/s10997-014-9295-8

6. Ibarra C.A. Investment, Asset Market, and the Relative Unit Labor Cost in Mexico. Economic Change and Restructuring, 2016, vol. 49, iss. 4, pp. 339-364. URL: https://doi.org/10.1007/s10644-015-9175-5

7. Haykin S. Neironnye seti: polnyi kurs [Neural Networks and Learning Machines]. Moscow, Vil'yams Publ., 2006, 1104 p.

8. Baestaens D.-E., van den Berg W.-M., Wood D. Neironnye seti i finansovye rynki: prinyatie reshenii v torgovykh operatsiyakh [Neural Network Solutions for Trading in Financial Markets]. Moscow, TVP Publ., 1997, 236 p.

9. Kruglov V.V., Borisov V.V. Iskusstvennye neironnye seti. Teoriya i praktika [Artificial neural networks. Theory and practice]. Moscow, Goryachaya liniya - Telekom Publ., 2002, 382 p.

10. Osovskii S. Neironnye seti dlya obrabotki informatsii [Neural networks for information processing]. Moscow, Finansy i Statistika Publ., 2002, 344 p.

11. Deboeck G.J., Kohonen T. Analiz finansovykh dannykh s pomoshch'yu samoorganizuyushchikhsya kart [Visual Explorations in Finance: With Self-Organizing Maps (Springer Finance)]. Moscow, AL'PINA Publ., 2001, 317 p.

12. Ignat'eva E.D., Mariev O.S. [The methodology and tools of structural-functional analysis of regional development]. Ekonomika regiona = Economy of Region, 2013, no. 1, pp. 227-239. (In Russ.)

13. Rastunkov V.S., Petrov A.K., Panov V.A. Neironnye seti. Statistica Neural Networks: Metodologiya i tekhnologiya sovremennogo analiza dannykh [Neural networks. STATISTICA Neural Networks: The methodology and technology of modern data analysis]. Moscow, Goryachaya liniya - Telekom Publ., 2008, 392 p.

14. Medvedev V.S., Potemkin V.G. Neironnye seti. MATLAB 6 [Neural networks. MATLAB 6]. Moscow, DIALOG-MIFI Publ., 2002, 122 p.

15. Kohonen T. Self-Organized Formation of Topologically Correct Feature Maps. Biological Cybernetics, 1982 , vol. 43, iss. 1, pp. 59-69. URL: https://doi.org/10.1007/BF00337288

16. Kohonen T. The Self-Organizing Map. Proceedings of the Institute of Electrical and Electronics Engineers, 1990, vol. 78, no. 9, pp. 1464-1480. URL: https://doi.org/10.1109/5.58325

Please cite this article as: Kuznetsov Yu.A., Perova V.I., Lastochkina E.I. A Neural Network Analysis of the Fixed Capital Investment Trends in 
17. Kohonen T., Oja E., Simula O., Visa A.J.E., Kangas J. Engineering Applications of the Self-Organizing Map. Proceedings of Institute of Electrical and Electronics Engineers, 1996, vol. 84, iss. 10, pp. 1358-1384. URL: https://doi.org/10.1109/5.537105

18. Rende S., Donduran M. Neighborhoods in Development: Human Development Index and Self-Organizing Maps. Social Indicators Research, 2013, vol. 110, iss. 2, pp. 721-734. URL: https://doi.org/10.1007/s11205-0119955-X

19. Carboni O.A., Russu P. Assessing Regional Wellbeing in Italy: An Application of Malmquist-DEA and Self-Organizing Map Neural Clustering. Social Indicators Research, 2015, vol. 122, iss. 3, pp. 677-700. URL: https://doi.org/10.1007/s11205-014-0722-7

20. Martinetz T.M., Berkovich S.G., Schulten K.J. “Neural-Gas” Network for Vector Quantization and Its Application to Time-Series Prediction. IEEE Transactions on Neural Networks, 1993, vol. 4, iss. 4, pp. 558-569.

\section{Conflict-of-interest notification}

We, the authors of this article, bindingly and explicitly declare of the partial and total lack of actual or potential conflict of interest with any other third party whatsoever, which may arise as a result of the publication of this article. This statement relates to the study, data collection and interpretation, writing and preparation of the article, and the decision to submit the manuscript for publication. 